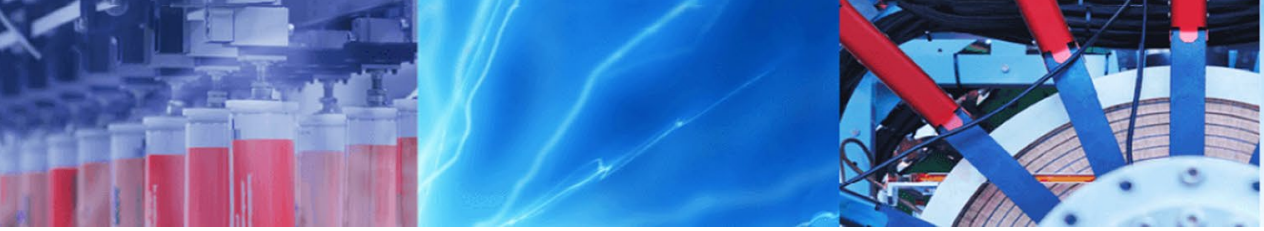

Research Article

\title{
Contamination of drinking water soon after cement mortar lining renovation depending on the disinfectant doses
}

\author{
Anna Młyńska ${ }^{1}$ - Michał Zielina ${ }^{1} \cdot$ Andrzej Bielski $^{1}$
}

C The Author(s) 2019 OPEN

\begin{abstract}
The quality of water transported through freshly cemented water pipes depends not only on the type of cement used. The other factor affecting the degree of leaching pollutants from cement coatings is the chemical parameters of the water. A disinfection process is necessary for maintaining water which is safe for human health and high quality. However, simultaneously, the presence of disinfectant in water may cause some problems. The results of the experiments performed showed that independently of the concentration of sodium hypochlorite in water, rapid changes of water $\mathrm{pH}$ soon after cement mortar lining renovation may always be expected. The addition of disinfectant to water causes an increase in pollutants leaching from cement coatings, even in the case of a low disinfectant dose. Although the concentration of disinfectant in water has a differential impact on the degree of pollutants leaching from cement coatings, the increase in the leaching of the pollutants is not proportional to the disinfectant concentration.
\end{abstract}

Keywords Cement coatings · Pipes · Renovation $\cdot$ Water $\cdot$ Disinfectant $\cdot$ Pollutants

\section{Introduction}

Many research papers report the various impacts of different cement types used for cement mortar lining renovation on the quality of transported water. In many cases, the degree of water contamination as a result of elements leaching from the protective cement coatings is strongly dependent on the composition of the cement used [1-4]. But the type of cement used for cementing water pipes is not the only factor to have an impact on water quality. It is well known that soft water exhibits aggressive properties in relation to the concrete compounds. In contact with concrete, soft water causes ions to be leached out of the cement mortar until the ion balance between the water phase and the cement liner is established.

The presence of 'aggressive' free carbon dioxide $\left(\mathrm{CO}_{2}\right)$ and the low content of carbonate $\left(\mathrm{CO}_{3}\right)$ and bicarbonate ions $\left(\mathrm{HCO}_{3}\right)$ in water are responsible for the aggressiveness of soft water. Leaching out of the calcium and hydroxide ions from the structure of hardened cement mortar leads to the creation of a poorly soluble calcium carbonate $\left(\mathrm{CaCO}_{3}\right)$ and then to the creation of an easily soluble calcium bicarbonate $\left(\mathrm{Ca}\left(\mathrm{HCO}_{3}\right)_{2}\right)$.

Because of the leaching of calcium compounds, the $\mathrm{pH}$ of concrete decreases and minerals which are durable under high $\mathrm{pH}$ conditions are dissolved. This causes the deterioration of the mechanical properties of the concrete. Moreover, the risk of water contamination is then greater [5-8].

One of the author's previous experiments [9] showed that soft water in contact with freshly cemented water pipelines is more vulnerable to an increase in water $\mathrm{pH}$ values and aluminium and chromium leaching than hard water. Similarly, Douglas and Merrill's experiments [10] indicate that water with a lower Langelier saturation index ('aggressive' water undersaturated with respect to $\mathrm{CaCO}_{3}$

\footnotetext{
Anna Młyńska, a.mlynska13@gmail.com; Michał Zielina, mziel@vistula.wis.pk.edu.pl; Andrzej Bielski, abielski@riad.pk.edu.pl| ${ }^{1}$ Department of Water Supply, Sewerage and Environmental Monitoring, Faculty of Environmental Engineering, Cracow University of Technology, ul. Warszawska 24, 31-155 Cracow, Poland.
} 
causes it to be dissolved [11]) contributes to the greater increase in water $\mathrm{pH}$ and alkalinity and calcium leaching. Thus, directly after renovation, a different impact of the quality of water inflowing to the water supply network on the leaching of pollutants from cement coatings and, eventually, the degree of water contamination can be expected.

Consumer tap water quality may be different from the water quality directly after purification processes. The quality of water transported from the water treatment plant to the consumer can deteriorate; the degree of water quality deterioration depends on many factors. It is known that among the many different factors, secondary water contamination depends on the chemical and biological quality of this water. The lack of biological or chemical stability of water leads to the secondary contamination phenomenon $[12,13]$. Improper or insufficient adjustment of water treatment processes in relation to the source water quality affects the further susceptibility of this water's biological parameters to deterioration. Biologically stable water should not support any adverse changes in bacteriological parameters $[14,15]$. In turn, lack of chemical water stability, as determined by some physico-chemical water indices, may lead to the electrochemical corrosion of metallic surfaces, or as was mentioned earlier, to calcium compounds being deposited and leached from pipes [16-19].

Considering the impact of some quality parameters of water produced in water treatment plants on secondary water contamination, in this paper, an analysis and comparison of the leaching of pollutants from cement coatings into three disinfected waters were performed. Because chemically instable water leads to the leaching of components from new concrete structures, it was decided to analyse whether any other factors, such as disinfectant concentration in water, also affect the leaching of pollutants directly after cement lining renovation. Namely, based on some analysed research papers [20-22], it can be supposed that when in contact with hardened cement mortar, disinfected water shows a different aggressiveness in relation to the cement compounds in comparison with disinfectant-free water. Moreover, the two-fold nature of disinfectants in water supply systems tends to support such an analysis. It is obvious that water disinfection is a very important process in safe-quality water production. On the one hand, the use of chemical agents limits the biological activity of many harmful pathogenic organisms, in this way making water safe for human health. But on the other hand, an excessive presence of chlorine compounds in the water may contribute to the deterioration of the water's taste and smell. Moreover, disinfectants may create harmful chemical by-products and accelerate pipe corrosion [23, 24]. As Polish regulation [25] determines, the limitation value for free chlorine or chloramines in drinking tap water is $0.30 \mathrm{mg} \mathrm{Cl} / \mathrm{dm}^{3}$ and $0.50 \mathrm{mg} \mathrm{Cl} / \mathrm{dm}^{3}$, respectively.

\section{Experimental section}

\subsection{Preparation of cement mortar-lined pipes}

In laboratory experiments, cemented pieces of water pipes were used. The internal surfaces all of the four steel water pipe pieces (pipes 1, 2, 3, 4) (Fig. 1) were covered manually with cement mortar. During the cement mortar lining process, it was sought to maintain similar conditions as during renovation under real conditions on a construction site. The description of the cemented water pipes used and cement coating preparation parameters are presented in Table 1.

After a 24-hour cement coating curing time, all of the four cemented water pipes were installed on separate test stands for the static experiments (Fig. 1).

\subsection{Water used in the experiments}

During the experiments, water with disinfectant and water without disinfectant was used. For preparing chlorinated water solutions, sodium hypochlorite $(\mathrm{NaOCl})$ with a concentration $C=153.8 \mathrm{mg} \mathrm{Cl} / \mathrm{dm}^{3}$ and water collected at the outflow from one of the water treatment plants for Cracow (Raba Treatment Plant, Poland) was used. $\mathrm{NaOCl}$ is an effective disinfectant, commonly used for disinfection processes in water treatment plants [26]. Three different concentrations of chlorinated water solutions were prepared: $C_{1} \approx 0.38 \mathrm{mg} \mathrm{Cl}_{2} / \mathrm{dm}^{3}, C_{2} \approx 0.16 \mathrm{mg} \mathrm{Cl} / \mathrm{dm}^{3}$ and $C_{3} \approx 0.076 \mathrm{mg} \mathrm{Cl}_{2} / \mathrm{dm}^{3}$. In turn, the water without disinfectant was water coming from the Raba Treatment Plant outflow (soft water).
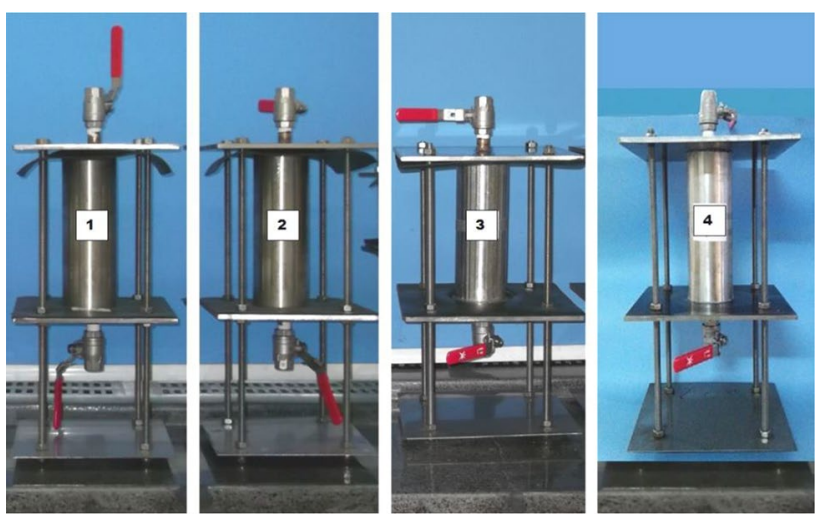

Fig. 1 Test stands with the cemented water pipes 
Table 1 Parameters of the cemented water pipes and cement coatings

\begin{tabular}{ll}
\hline Water pipe & \\
Material & Steel \\
Length & $25 \mathrm{~cm}$ \\
Nominal diameter & $82 \mathrm{~mm}$ \\
Internal volume without cement & $1.320 \mathrm{dm}^{3}$ \\
$\quad$ coating & \\
Internal volume including cement & $0.934 \mathrm{dm}^{3}$ \\
$\quad$ coating thickness & \\
Cement coating & \\
Cement type & Portland cement CEM I 42.5 R \\
Sand type & Quartz sand $(0.4 \div 0.8 \mathrm{~mm})$ \\
Water-to-cement ratio & $0.35[\mathrm{~kg}$ water $/ \mathrm{kg}$ cement $]$ \\
Sand-to-cement ratio & $1: 1[\mathrm{~kg} \mathrm{sand} / \mathrm{kg}$ cement $]$ \\
Thickness & $0.65 \mathrm{~cm}^{2}$ \\
Surface area & $541.92 \mathrm{~cm}{ }^{2}$ \\
Curing time & $24 \mathrm{~h}$ \\
\hline
\end{tabular}

\subsection{Laboratory experiments}

The experiments were carried out under water stagnation conditions. The cemented water pipes were simultaneously filled with a chlorinated water solution immediately after its preparation (pipe $1-C_{1} \approx 0.38 \mathrm{mg} \mathrm{Cl}_{2} / \mathrm{dm}^{3}$, pipe $2-C_{2} \approx 0.16 \mathrm{mg} \mathrm{Cl}_{2} / \mathrm{dm}^{3}$, pipe $3-C_{3} \approx 0.076 \mathrm{mg} \mathrm{Cl}_{2} / \mathrm{dm}^{3}$ and pipe 4-water without disinfectant). The volume of water filling the pipes was less than $1.0 \mathrm{dm}^{3}$. Each of the four tested waters remained in contact with the cemented pipes for the same period of time, in a temperature of about $23^{\circ} \mathrm{C}$. Based on the Netherlands [27] and Polish [28] standards, the schedule of collecting water samples was elaborated. After 1, 2, 4, 7, 9, 12, 16, 19, 36 and 64 days, water was collected from test stands and investigated in the laboratory for different water quality indices, such as $\mathrm{pH}$ and chemical element concentrations, including calcium, aluminium, chromium and lead. Subsequently, the emptied pieces of pipes were refilled with the same water types used at the start of the earlier experiment.

\subsection{Results elaboration methods}

Based on the measured element concentrations in the water and based on Eqs. (1) and (2) [27], it was possible to count the chemical elements leaching from the $1 \mathrm{~m}^{2}$ of cement coating surface area after contact with the chlorinated waters (sodium hypochlorite concentration $C_{1}, C_{2}$ and $C_{3}$ ) and with the water with no disinfectant (Fig. 3). Cumulative leaching graphs (Fig. 3) enabled a comparison of the degree of the process of pollutants leaching from the cement coatings after their contact with different water types, including a comparison of the leaching intensity within the whole investigation period (Tables 2 , 3,4 and 5), and a comparison of the total leached amounts of chemical elements noted at the end of the 64-day investigation period (Fig. 4).

$E_{i}=\frac{C_{i} \cdot V}{A}$

$E_{n}=\sum_{i=1}^{n} E_{i}$

where $E_{i}$-leaching of chemical element from the cement coating unit area, $\left(\mathrm{mg} / \mathrm{m}^{2}\right), C_{i}$-measured chemical element concentration in the collected water sample, (mg/ $\left.\mathrm{dm}^{3}\right), V$ - the volume of water in contact with cement coating, $\left(\mathrm{dm}^{3}\right), A$-the surface area of cement coating, $\left(\mathrm{m}^{2}\right)$, $E_{n}$-cumulative leaching of a chemical element from the cement coating unit area, $\left(\mathrm{mg} / \mathrm{m}^{2}\right)$ and $n$-number of the water replacement.

\section{Results and discussion}

During the experiments, independently of the disinfectant concentration in water, rapid growth of water $\mathrm{pH}$ in the initial period of contact with the cement coatings was observed (Fig. 2). Mostly, the differences between the water $\mathrm{pH}$ in the case of various sodium hypochlorite concentrations were almost unnoticeable. The changes of water $\mathrm{pH}$ values for the whole 64-day investigation period were very similar in all of the four tested water types. It can be stated that the concentration of disinfectant in water has no meaningful impact on the degree of $\mathrm{pH}$ changes which take place soon after renovation of the cement lining. Directly after the renovation, a rapid growth of $\mathrm{pH}$ value, exceeding 12.0, may always be expected. In addition, further increases in water $\mathrm{pH}$ values can be observed for quite some time. The research results presented by Clark [20] and Deb et al. [21] also indicate that there is no significant impact of the disinfectant type or its concentration in water on $\mathrm{pH}$ changes after contact with hardened cement mortar.

It was observed that the addition of disinfectant to water causes an increase in the leaching of pollutants from cement coatings. Moreover, even the lowest disinfectant dose causes a considerable increase in leaching of pollutants (Fig. 3).

In contrast to the $\mathrm{pH}$ changes, the concentration of disinfectant in water has a differential impact on the leaching of pollutants from cement coatings (Fig. 3). Nevertheless, there was no observed proportionality of the increase in the leaching of pollutants in relation to the disinfectant 
Table 2 Calcium leaching intensity from cement coatings into different water types

\begin{tabular}{|c|c|c|c|c|c|}
\hline \multirow[t]{2}{*}{ Time (days) } & \multirow{2}{*}{$\begin{array}{l}\text { Time inter- } \\
\text { val (days) }\end{array}$} & \multicolumn{4}{|c|}{ Leaching intensity $\left(\mathrm{mg} \mathrm{Ca} / \mathrm{m}^{2} /\right.$ day $)$} \\
\hline & & $\begin{array}{l}\mathrm{C}_{1} \\
\sim 0.38 \mathrm{mg} \mathrm{Cl} / \mathrm{dm}^{3}\end{array}$ & $\begin{array}{l}\mathrm{C}_{2} \\
\sim 0.16 \mathrm{mg} \mathrm{Cl} / \mathrm{dm}^{3}\end{array}$ & $\begin{array}{l}\mathrm{C}_{3} \\
\sim 0.076 \mathrm{mg} \\
\mathrm{Cl}_{2} / \mathrm{dm}^{3}\end{array}$ & No disinfectant \\
\hline \multicolumn{6}{|l|}{0} \\
\hline & 1 & 339.52 & 1144.86 & 659.16 & 354.24 \\
\hline \multicolumn{6}{|l|}{1} \\
\hline & 1 & 839.68 & 357.74 & 694.32 & 695.86 \\
\hline \multicolumn{6}{|l|}{2} \\
\hline & 2 & 440.78 & 0.00 & 376.23 & 289.09 \\
\hline \multicolumn{6}{|l|}{4} \\
\hline & 3 & 0.00 & 0.00 & 117.66 & 0.00 \\
\hline \multicolumn{6}{|l|}{7} \\
\hline & 2 & 85.58 & 0.00 & 0.00 & 0.00 \\
\hline \multicolumn{6}{|l|}{9} \\
\hline & 3 & 0.00 & 0.00 & 0.00 & 0.00 \\
\hline \multicolumn{6}{|l|}{12} \\
\hline & 4 & 0.00 & 0.00 & 0.00 & 0.00 \\
\hline \multicolumn{6}{|l|}{16} \\
\hline & 3 & 0.00 & 0.00 & 0.00 & 0.00 \\
\hline \multicolumn{6}{|l|}{19} \\
\hline & 17 & 0.00 & 0.00 & 0.00 & 0.00 \\
\hline \multicolumn{6}{|l|}{36} \\
\hline & 28 & 0.00 & 0.00 & 0.00 & 0.00 \\
\hline 64 & & & & & \\
\hline
\end{tabular}

concentration. The chlorinated water with the lowest sodium hypochlorite concentration $\left(C_{3} \approx 0.076 \mathrm{mg} \mathrm{Cl}_{2} /\right.$ $\mathrm{dm}^{3}$ ) turned out to be the most aggressive in relation to the calcium (Fig. 3a), aluminium (Fig. 3b) and chromium (Fig. 3c) compounds in the cement coatings. It resulted in leaching of the greatest total amounts of elements from the cement coating into the water with $\mathrm{C}_{3}$ disinfectant concentration (Fig. 4).

In the case of calcium (Fig. 3a), the chlorinated water with $\mathrm{C}_{2}$ disinfectant concentration did not cause significant leaching of calcium compounds in the next days of the experiments, except on the first day. Calcium leaching intensity recorded then was the greatest from among all of the four water types (Table 2). Nevertheless, at the end of the 64-day investigation period, the total amount of leached calcium from the cement coating in the case of the $C_{2}$ water was smaller by about $40 \%$ than in the case of the $C_{3}$ concentration (Fig. 4). During the experiments, it was observed that disinfectant concentration in water has an impact on the degree of calcium leaching from the newly installed cement coatings. Leaching intensity can be visibly different, especially in the initial period of contact of the cement coatings with chlorinated waters of different concentrations (Table 2). Research results presented by Clark [20] confirm that the calcium leaching process on the first day of contact of fresh hardened cement mortar with water with different disinfectant types, or its concentrations, may vary in significance. Similarly to the obtained laboratory experiments results, Clark's results [20] show that the longer the time of concrete exploitation, the less the disinfectant concentration will affect the degree of calcium leaching. This was the same in all of the four tested waters; after the most intensive calcium leaching in the initial period of contact with the cement coatings, the leaching process ceased after a few days.

Similarly to the calcium compounds, the chlorinated water with $C_{2}$ disinfectant concentration caused the lowest aluminium leaching, but in this case it was noted for the whole investigation period (Fig. 3b, Table 3). This resulted in a total amount of leached aluminium in the case of the $C_{2}$ concentration water in the amount of $43.60 \mathrm{mg} / \mathrm{m}^{2}$ (Fig. 4). This value ranged from more than two times to more than three times lower than in the case of the other tested waters. Although the most intensive aluminium leaching from the cement coating is expected soon after the cement lining renovation, independently of the sodium hypochlorite concentration, a leaching process with very weak intensity may be observed for a longer time than, for example, calcium leaching (Table 3).The confirmation of the various impacts of disinfectant type or its 
Table 3 Aluminium leaching intensity from cement coatings into different water types

\begin{tabular}{|c|c|c|c|c|c|}
\hline \multirow[t]{2}{*}{ Time (days) } & \multirow{2}{*}{$\begin{array}{l}\text { Time interval } \\
\text { (days) }\end{array}$} & \multicolumn{4}{|c|}{ Leaching intensity ( $\mathrm{mg} \mathrm{Al} / \mathrm{m}^{2} /$ day) } \\
\hline & & $\begin{array}{l}C_{1} \\
\sim 0.38 \mathrm{mg} \mathrm{Cl}_{2} / \\
\mathrm{dm}^{3}\end{array}$ & $\begin{array}{l}C_{2} \\
\sim 0.16 \mathrm{mg} \mathrm{Cl}_{2} / \\
\mathrm{dm}^{3}\end{array}$ & $\begin{array}{l}C_{3} \\
\sim 0.076 \mathrm{mg} \mathrm{Cl}_{2} / \\
\mathrm{dm}^{3}\end{array}$ & No disinfectant \\
\hline \multicolumn{6}{|l|}{0} \\
\hline & 1 & 67.21 & 19.45 & 89.00 & 43.24 \\
\hline \multicolumn{6}{|l|}{1} \\
\hline & 1 & 3.43 & 19.79 & 27.82 & 24.60 \\
\hline \multicolumn{6}{|l|}{2} \\
\hline & 2 & 11.33 & 0.65 & 14.06 & 10.19 \\
\hline \multicolumn{6}{|l|}{4} \\
\hline & 3 & 4.07 & 0.00 & 1.10 & 1.75 \\
\hline \multicolumn{6}{|l|}{7} \\
\hline & 2 & 3.24 & 0.00 & 0.11 & 0.00 \\
\hline \multicolumn{6}{|l|}{9} \\
\hline & 3 & 0.50 & 0.00 & 0.00 & 0.04 \\
\hline \multicolumn{6}{|l|}{12} \\
\hline & 4 & 0.09 & 0.00 & 0.00 & 0.05 \\
\hline \multicolumn{6}{|l|}{16} \\
\hline & 3 & 0.00 & 0.00 & 0.00 & 0.00 \\
\hline \multicolumn{6}{|l|}{19} \\
\hline & 17 & 0.07 & 0.01 & 0.05 & 0.05 \\
\hline \multicolumn{6}{|l|}{36} \\
\hline & 28 & 0.04 & 0.01 & 0.07 & 0.02 \\
\hline 64 & & & & & \\
\hline
\end{tabular}

concentration on aluminium release from freshly cured cement mortar to the water are Clark's results [20] that are presented in the author's research paper.

The results obtained from the experiments show a significant difference between the chromium leaching from the cement coating to the chlorinated water with sodium hypochlorite concentration $C_{3} \approx 0.076 \mathrm{mg} \mathrm{Cl} / \mathrm{dm}^{3}$ and the water with no disinfectant (Fig. 3c). While in the case of other chemical elements analysis, disinfectantfree water caused a quite similar leaching as chlorinated waters, in the case of chromium, the leaching process to the water with no disinfectant was weaker in comparison with the disinfected waters. Both leaching intensity values presented in Table 4 and the total leached amounts of chemical elements graph (Fig. 4) confirm the much smaller aggressiveness of non-disinfected water in relation to the chromium compounds than the other water types, and a similar chromium leaching process in all of the three disinfected waters.

The lead leaching process from the cement coatings was tested only for two prepared water types: for water with the highest sodium hypochlorite concentration $\left(C_{1} \approx 0.38 \mathrm{mg}\right.$
$\mathrm{Cl}_{2} / \mathrm{dm}^{3}$ ) and for water with no disinfectant. In the first day of the experiments, lead leaching intensity in both cases was the same (Table 5). When, on the next day, the lead leaching process ceased in the non-disinfected water, the disinfected water was still causing leaching of the element. The result of this was a significant growth of leached lead in the second day of the experiments (Fig. 3d). What is more, as noted at the end of the 64-day investigation period, the total amount of leached lead was three times greater in the case of chlorinated water than in the case of the water without disinfectant (Fig. 4).

To compare the obtained laboratory experiments results with the results of other authors, a research paper of Kowalska et al. [22] shows that chlorinated water causes more intensive leaching of the main cement components, especially calcium and potassium, than chlorine-free water. In turn, an intensification of release of trace elements from the cement coating to the disinfected water was not observed. The authors of the paper [22] highlight the significant impact of chlorinated water on the solubility of hardened cement mortar components in comparison with non-disinfected water. 
Table 4 Chromium leaching intensity from cement coatings into different water types
Table 5 Lead leaching intensity from cement coatings into different water types

\begin{tabular}{|c|c|c|c|c|c|}
\hline \multirow[t]{2}{*}{ Time (days) } & \multirow{2}{*}{$\begin{array}{l}\text { Time interval } \\
\text { (days) }\end{array}$} & \multicolumn{4}{|c|}{ Leaching intensity ( $\mathrm{mg} \mathrm{Cr} / \mathrm{m}^{2} /$ day) } \\
\hline & & $\begin{array}{l}\mathrm{C}_{1} \\
\sim 0.38 \mathrm{mg} \mathrm{Cl}_{2} / \\
\mathrm{dm}^{3}\end{array}$ & $\begin{array}{l}\mathrm{C}_{2} \\
\sim 0.16 \mathrm{mg} \mathrm{Cl}_{2} / \\
\mathrm{dm}^{3}\end{array}$ & $\begin{array}{l}\mathrm{C}_{3} \\
\sim 0.076 \mathrm{mg} \mathrm{Cl}_{2} / \\
\mathrm{dm}^{3}\end{array}$ & No disinfectant \\
\hline \multicolumn{6}{|l|}{0} \\
\hline & 1 & 0.304 & 0.468 & 0.486 & 0.089 \\
\hline \multicolumn{6}{|l|}{1} \\
\hline & 1 & 0.114 & 0.072 & 0.099 & 0.068 \\
\hline \multicolumn{6}{|l|}{2} \\
\hline & 2 & 0.059 & 0.020 & 0.068 & 0.048 \\
\hline \multicolumn{6}{|l|}{4} \\
\hline & 3 & 0.040 & 0.00 & 0.034 & 0.023 \\
\hline \multicolumn{6}{|l|}{7} \\
\hline & 2 & 0.043 & 0.00 & 0.017 & 0.00 \\
\hline \multicolumn{6}{|l|}{9} \\
\hline & 3 & 0.017 & 0.00 & 0.00 & 0.00 \\
\hline \multicolumn{6}{|l|}{12} \\
\hline & 4 & 0.00 & 0.00 & 0.00 & 0.00 \\
\hline \multicolumn{6}{|l|}{16} \\
\hline & 3 & 0.00 & 0.00 & 0.00 & 0.00 \\
\hline \multicolumn{6}{|l|}{19} \\
\hline & 17 & 0.00 & 0.00 & 0.00 & 0.00 \\
\hline \multicolumn{6}{|l|}{36} \\
\hline & 28 & 0.00 & 0.00 & 0.00 & 0.00 \\
\hline 64 & & & & & \\
\hline
\end{tabular}

\begin{tabular}{|c|c|c|c|c|c|}
\hline \multirow[t]{2}{*}{ Time (days) } & \multirow{2}{*}{$\begin{array}{l}\text { Time inter- } \\
\text { val (days) }\end{array}$} & \multicolumn{4}{|c|}{ Leaching intensity (mg Pb/m²/day) } \\
\hline & & $\begin{array}{l}\mathrm{C}_{1} \\
\sim 0.38 \mathrm{mg} \\
\mathrm{Cl}_{2} / \mathrm{dm}^{3}\end{array}$ & $\begin{array}{l}\mathrm{C}_{2} \\
\sim 0.16 \mathrm{mg} \mathrm{Cl} / \mathrm{dm}^{3}\end{array}$ & $\begin{array}{l}\mathrm{C}_{3} \\
\sim 0.076 \mathrm{mg} \mathrm{Cl}_{2} / \mathrm{dm}^{3}\end{array}$ & No disinfectant \\
\hline 0 & 1 & 0.036 & $\begin{array}{l}\text { No } \\
\text { measurement }\end{array}$ & $\begin{array}{l}\text { No } \\
\text { measurement }\end{array}$ & 0.035 \\
\hline & 1 & 0.057 & & & 0.00 \\
\hline 2 & 2 & 0.00 & & & 0.00 \\
\hline 4 & 3 & 0.00 & & & 0.00 \\
\hline 7 & 2 & 0.00 & & & 0.00 \\
\hline 9 & 3 & 0.00 & & & 0.00 \\
\hline 12 & 4 & 0.00 & & & 0.00 \\
\hline 16 & 3 & 0.00 & & & 0.00 \\
\hline 19 & 17 & 0.00 & & & 0.00 \\
\hline 36 & 28 & 0.00 & & & 0.00 \\
\hline 64 & & & & & \\
\hline
\end{tabular}




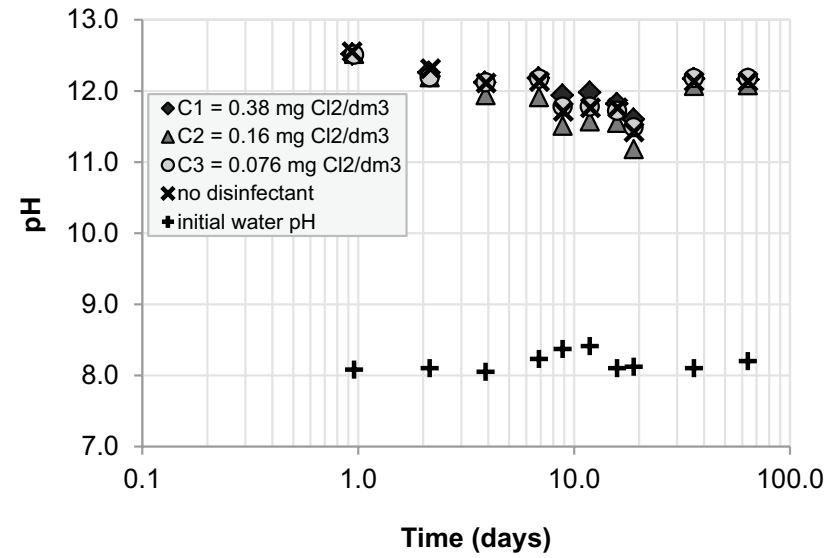

Fig. 2 Water $\mathrm{pH}$ values after contact with the cement coatings

\section{Conclusions}

There are many reasons for secondary drinking water contamination in water supply systems; one of the most significant is the parameters of water produced in water treatment plants. The achievement of the chemical and biological stability of water inflowing to the water network minimises the risk of the deterioration of water quality delivered to the consumer. The lack of chemical stability of water flowing through pipelines with internal cement coatings may lead to the leaching of cement compounds,
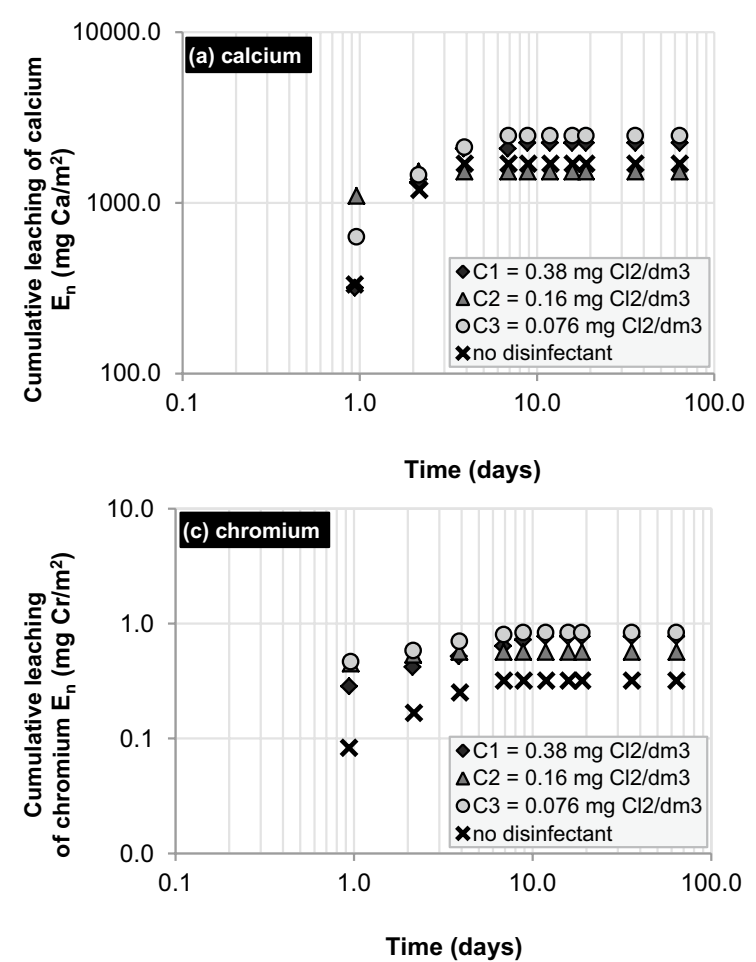

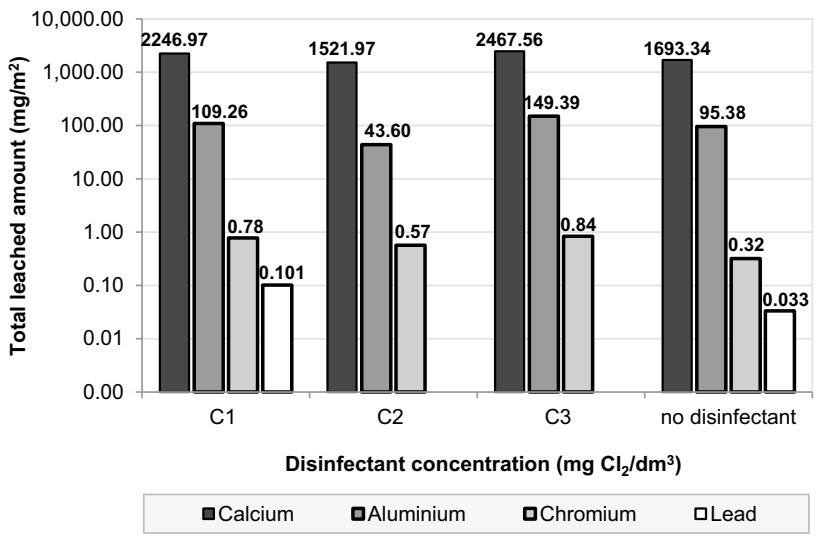

Fig. 4 Total amounts of leached elements from cement coatings into different water types noted at the end of 64-day investigation period

thus contributing to the water contamination, e.g. as in case of 'aggressive' soft water.

In this paper, an analysis and comparison of the leaching of some pollutants from cement coatings into disinfected waters directly after renovation of the water pipes were performed. This is in order to determine if there are any other factors related to the water quality parameters affecting the degree of leaching of pollutants from freshly cemented pipelines. As it turns out, the concentration of sodium hypochlorite has little relevant impact
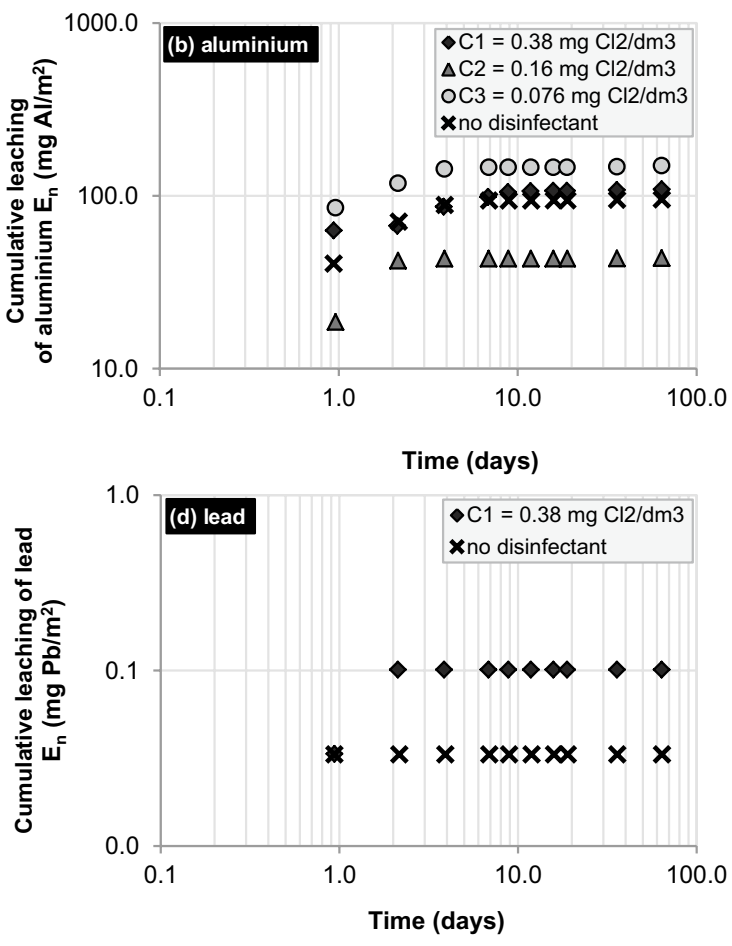

Fig. 3 Cumulative leaching of elements from cement coatings into different water types 
on the changes in water $\mathrm{pH}$ after its contact with the raw cement coatings. Independently of the disinfectant concentration, cement coatings cause a similarly rapid increase in $\mathrm{pH}$ values. In general, as experimental results showed, adding a disinfectant to water contributes to the considerable growth of the leaching of pollutants. In the case of calcium, aluminium, chromium and lead leaching from cement coatings into disinfected waters and into disinfectant-free water, more visible differences were observed than in case of $\mathrm{pH}$. However, as was observed, the increase in leached pollutants in waters was not proportional to the disinfectant concentrations. The disinfected water with the lowest sodium hypochlorite concentration $\left(C_{3} \approx 0.076 \mathrm{mg} \mathrm{Cl}_{2} / \mathrm{dm}^{3}\right)$ turned out to be the most aggressive in relation to the calcium, aluminium and chromium compounds, causing its leaching in the greatest amounts.

It is known that water disinfection during purification processes in water treatment plants is necessary for safequality water production and to prevent and limit the secondary water pollution phenomenon. However, the presence of disinfectants in water may have a negative impact on some organoleptic water parameters. Additionally, the performed experiments show that disinfected water may have an indirect impact on water quality. As it turns out, the degree of the leaching of pollutants from cement structures is also related to the presence of disinfectant in water and its concentration.

\section{Compliance with ethical standards}

Conflict of interest On behalf of all the authors, the corresponding author states that there is no conflict of interest.

Open Access This article is distributed under the terms of the Creative Commons Attribution 4.0 International License (http://creativeco mmons.org/licenses/by/4.0/), which permits unrestricted use, distribution, and reproduction in any medium, provided you give appropriate credit to the original author(s) and the source, provide a link to the Creative Commons license, and indicate if changes were made.

\section{References}

1. Meland IS (1999) Durability of mortar linings in ductile iron pipes. In: Durability of building materials and components 8: Proceedings of the eighth international conference on durability of building materials and components, Institute for Research and Construction, Vancouver, pp 170-179

2. Zielina M, Dąbrowski W, Radziszewska-Zielina E (2014) Cement mortar lining as a potential source of water contamination. World Acad Sci Eng Technol 8(10):636-639

3. Młyńska A, Zielina M (2017) The influence of prefabricated pipe cement coatings and those made during pipe renovation on drinking water quality. In: E3S web of conferences, 9th conference on interdisciplinary problems in environmental protection and engineering EKO-DOK 2017, April 23-25, Boguszów-Gorce, Poland 17

4. Młyńska A, Zielina M (2018) A comparative study of portland cements CEM I used for water pipe renovation in terms of pollutants leaching from cement coatings and their impact on water quality. J Water Supply Res Technol AQUA 67(7):685-696

5. Ekström T (2001) Leaching of concrete. Experiments and modeling. Report TVBM-3090, Lund Institute of Technology, Division of Building Materials, Sweden

6. Bonds RW (2005) Cement-mortar linings for ductile iron pipe. Report DIP-CML/3-05/3.5 M, Ductile Iron Pipe Research Association (DIPRA), Alabama, USA

7. Ballim Y (2012) Physical and chemical deterioration processes. Postgraduate lecture, School of Civil \& Environmental Engineering, University of Witwatersrand, Johannesburg

8. Hall SC (2013) Corrosion protection provided by mortar lining in large diameter water pipelines after many years of service. Pipelines 2013 Conference, June 23-26, Texas, USA, pp 100-112

9. Młyńska A, Zielina M (2016) Experimental research on the impact of different hardness waters on their contamination by protective cement mortar linings after pipe renovation. Tech Trans Environ Eng 1-Ś:97-104

10. Douglas BD, Merrill DT (1991) Control of water quality deterioration caused by corrosion of cement-mortar pipe linings (Report). AWWA, Denver

11. McTigue NE, Symons JM (2010) The water dictionary: a comprehensive reference of water terminology, 2nd edn. AWWA, Denver

12. WHO (2014) Water safety in distribution systems. WHO, Geneva

13. Jachimowski $A$ (2017) Factors affecting water quality in water supply network. J Ecol Eng 18:110-117

14. Srinivasan S, Harrington GW (2007) Biostability analysis for drinking water distribution systems. Water Res 41(10):2127-2138

15. Prest El, Hammes F, van Loosdrecht MCM, Vrouwenvelder JS (2016) Biological stability of drinking water: controlling factors, methods, and challenges. Front Microbiol 7:45

16. AwwaRF (1996) Internal corrosion of water distribution systems, 2nd edn. AwwaRF, Denver

17. Pietrucha-Urbanik K, Tchórzewska-Cieślak B, Papciak D, Skrzypczak I (2017) Analysis of chemical stability of tap water in terms of required level of technological safety. Arch Environ Prot 43(4):3-12

18. Młyńska A, Zielina M (2019) Estimation of pollutants leaching from cement coating to water after pipe renovation based on laboratory experiments. Clean Soil Air Water 47(4):1-8

19. Zielina M, Dąbrowski W, Lang T (2007) Assessing the risk of corrosion of asbestos-cement pipes in Kraków's water supply network. Environ Prot Eng 33(4):17-26

20. Clark DD (2009) Water quality, aesthetic and corrosion inhibitor implications of newly installed cement mortar lining used to rehabilitate drinking water pipelines. Master's Thesis, Virginia Polytechnic Institute and State University, Blacksburg

21. Deb A, McCammon SB, Snyder J, Dietrich A (2010) Impacts of lining materials on water quality. Water Research Foundation, Denver

22. Kowalska B, Kowalski D, Kwietniewski M, Musz A, Wąsowski J (2010) Ocena wpływu wykładziny cementowej w rurociągach żeliwnych na jakość przesyłanej wody-badania wstępne. [Evaluation of the influence of concrete lining in cast iron pipeline systems on the quality of transported water-introductory research]. Gaz, Woda i Technika Sanitarna 4:13-17

23. Lahlou MZ (2002) Water quality in distribution systems. Tech Brief. A national drinking water clearing house fact sheet, West Virginia University 
24. WHO (2011) Guidelines for drinking-water quality, 4th edn. WHO, Geneva

25. Rozporządzenie Ministra Zdrowia z dnia 7 grudnia 2017 roku w sprawie jakości wody przeznaczonej do spożycia przez ludzi (Dz.U. 2017 poz. 2294). [Regulation of the Minister of Health of 7 December 2017 on the water quality intended for human consumption]

26. Solutions Intratec (2013) Technology economics: sodium hypochlorite chemical production. Intratec Solutions, Houston

27. EA NEN 7375:2004 Leaching characteristics of moulded or monolithic building and waste materials/determination of leaching of inorganic components with the diffusion test- "The tank test". Netherlands Normalization Institute Standard

28. PN-EN 14944-3:2008 Influence of cementitious products on water intended for human consumption. Test methods. Migration of substances from factory-made cementitious products

Publisher's Note Springer Nature remains neutral with regard to jurisdictional claims in published maps and institutional affiliations. 